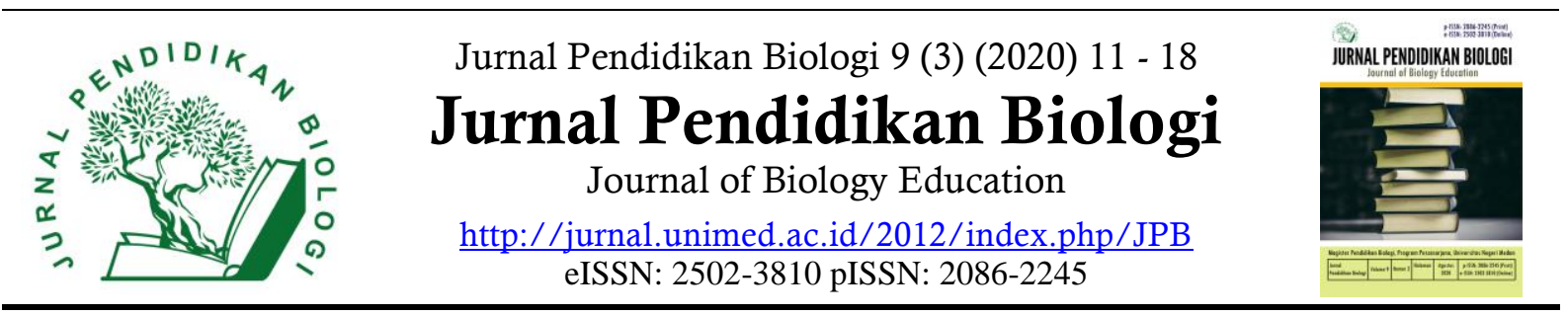

\title{
Pengaruh Laboratorium Virtual Biologi Berbasis Problem Solving Terhadap Kemampuan Berpikir Kritis Mahasiswa
}

\author{
Ewi Mellysa Br Barus ${ }^{1^{*}}$, Terry Noviar Panggabean ${ }^{2}$ \\ $I^{*}$ Pharmacist Departement, Imelda University Of Medan, North Sumatera, Indonesia, 20239 \\ ${ }^{2}$ Medical Record Departement, Imelda University Of Medan, North Sumatera, Indonesia, 20239
}

\section{INFO ARTIKEL}

\section{Histori Artikel}

Received 26 September 2020

Revised 25 Oktober 2020

Accepted 8 Nopember 2020

Published 28 Nopember 2020

\section{Keywords:}

Critical Thinking,

Virtual Laboratory,

Problem Solving

\begin{abstract}
The availability of facilities and infrastructure in learning Cell and molecular biology courses is needed to support the achievement of learning objectives. Based on the results of observations in the Imelda University, Pharmacy Department, the lack of implementation due to the lack of facilities and infrastructure that support the practicum causes a lack of improvement in students' critical thinking skills. The ability to think critically is the main factor affecting student understanding. In this case, the media that can support this is a problem solving-based virtual laboratory to encourage students' critical thinking skills. This study aims to identify the effect of a problem solving-based virtual biology laboratory on the critical thinking skills of students in the Pharmacy Undergraduate Study Program at Imelda University, Medan. The research design was one group pre-test posttest. Data collection was carried out starting in January 2020, followed by data processing and analysis. The sample in this study were all students of the first semester Pharmacy Department at Imelda University, totaling 63 people. The sampling technique in this study is total sampling. The statistical analysis used was one sample T-test. Based on the results of the discussion based on the problems and research objectives, it can be concluded that there is a positive and significant effect with $\mathrm{p} 0.00<0.05$ in the use of problem solving-based virtual laboratories on students' critical thinking skills in the cell and molecular biology courses at the Imelda University Pharmacy Department. With the virtual laboratory, students learn the principles of science in a fast, effective and fun way through virtual laboratory interactions and navigation.
\end{abstract}

Copyright (C) 2020 Universitas Negeri Medan. Artikel Open Access dibawah lisensi CC-BY-4.0 (https://creativecommons.org/licenses/by/4.0)

How to Cite

Barus, E.M \& Panggabean, T. N. (2020). Pengaruh Laboratorium Virtual Biologi Berbasis Problem Solving Terhadap Kemampuan Berpikir Kritis Mahasiswa. Jurnal Pendidikan Biologi, 9(3), 11-18.

\section{PENDAHULUAN}

Pemanfaatan teknologi informasi dalam pembelajaran berbasis komputer semakin meningkat dan lambat laun akan diadaptasikan ke berbagai bidang. Perpaduan antara teknologi informasi dan pendekatan pembelajaran yang tepat telah menunjukkan potensi yang sangat besar untuk diintegrasikan dalam bidang pendidikan (Faovor \& Ayoubi, 
2018). Pada tingkat universitas penggunaan teknologi dalam pengajaran biologi sangat diperlukan (Peat \& Fernandez, 2000). Pendekatan pembelajaran berbasis problem solving menempatkan peserta didik dalam situasi yang menghadapkan mereka pada masalah, tantangan, dilema dan mendorong peserta didik untuk menerapkan pengetahuan dan keterampilan praktik yang relevan sesuai dengan situasi dan kondisi (Karantzas, et al., 2013). Teknologi virtual secara umum, dan pendekatan pembelajaran berbasis problem solving secara khusus, ketika diintegrasikan ke dalam sistem dapat meningkatkan pengajaran dan pembelajaran, hal tersebut telah terbukti menjadi alat yang menjanjikan untuk membantu peserta didik memperoleh pengetahuan dalam sains (Muhamad \& Ahmad, 2011). Selain itu, kemajuan teknologi seperti simulasi dan teknologi virtual juga dapat meningkatkan konstruksi analogi fenomena alam melalui representasi visual dan simulasi realistik berdasarkan fenomena nyata (Sommer \& Sommer, 2003). Laboratorium virtual adalah salah satu rangkaian teknologi berbasis komputer terbaru yang dapat meningkatkan kemungkinan interaktivitas. Laboratorium virtual memiliki aplikasi signifikan di bidang komputasi yang membawa pengguna ke lingkungan sintetis. Laboratorium virtual umumnya diklasifikasikan menurut jenis teknologi yang digunakan untuk mengembangkan pembelajaran mulai dari 'sepenuhnya imersif' di mana pengguna diisolasi dari pengaruh dunia nyata, hingga laboratorium virtual 'non-imersif yang juga disebut desktop (Stuckey \& Stuckey, 2017). Laboratorium virtual mensituasikan pengguna masih sadar akan dunia visual luar (Jorda, 2013).

Melalui kegiatan laboratorium, peserta didik dapat mempelajari sains dengan pengamatan langsung terhadap fenomena sains dan melatih serta meningkatkan kemampuan berpikir ilmiah, menanamkan dan mengembangkan sikap ilmiah, menemukan dan memecahkan berbagai masalah baru melalui metode ilmiah (Nasution \& Ashar, 2016). Berdasarkan hasil observasi dan penilaian hasil belajar mahasiswa khususnya pada mata kuliah biologi sel dan molekuler di Program Studi Pendidikan Farmasi, Universitas Imelda Medan (UIM) pada umumnya dibutuhkan peningkatan kemampuan berpikir kritis mahasiswa pada saat praktikum. Hal tersebut sebagai dampak dari minimmnya kegiatan praktikum. Kegiatan praktikum dilaboratorium pada mata kuliah biologi sel dan molekuler tidak dapat dilaksanakan secara maksimal dikarenakan adanya keterbatasan sarana dan prasarana serta minimnya kemampuan peserta didik dalam memecahkan masalah.

Problem solving adalah sebuah pendekatan yang merangsang peserta didik untuk belajar melalui keterlibatan dalam masalah nyata. Oleh karena itu, problem solving merupakan elemen penting yang menuntun untuk bekerja dengan memecahkan masalah dunia nyata, berkolaborasi dengan rekan kerja, dan fokus pada pertanyaan kritis yang membingkai masalah tersebut (Bidokhta \& Assareh, 2011). Selain belajar metode, faktor internal yang ada pada peserta didik juga harus diperhatikan untuk mendapatkan keberhasilan pembelajaran biologi, seperti keterampilan berpikir kritis peserta didik, belajar motivasi, gaya belajar, keterampilan peserta didik, sikap, dan lain-lain. Problem solving sebagai salah satu pembelajaran model memiliki ciri khas yaitu dimulai dan berpusat pada pemecahan masalah, produksi alat praktikum, prosedur kerja / langkah dan pembuatannya observasi (Rene \& Jose, 2018).

Keterbatasan sarana dan prasarana pada laboratorium dan rendahnya kemampuan berpikir kritis peserta didik menuntut perlunya pendekatan secara virtual dalam bentuk 
animasi pembelajaran sehingga kegiatan laboratorium biologi semakin lebih real untuk dilaksanakan. Dengan memanfaatkan laboratorium biologi virtual di Prodi S1 Farmasi, mahasiswa memiliki pengalaman secara real untuk berhadapan dengan percobaan yang akan dilakukan. Pembelajaran prakitkum berbasis virtual dapat memperkenalkan hal-hal yang berkaitan dengan ruang lingkup biologis secara lebih nyata. Mengikutsertakan Problem solving dalam pelaksaaan laboratorium berbasis virtual pada ilmu biologi merupakan bentuk yang perlu diterapkan dalam setiap kegiatan praktikum di perguruan tinggi khususnya di program studi S1 Farmasi, sehingga mahasiswa memiliki kemampuan berpikir kritis terkhusus di dalam pembelajaran biologi. Konsep virtual berbasis problem solving sangat mendukung dengan visi perguruan tinggi untuk menghasilkan lulusan yang unggul dan bersaing sesuai dengan kompetensinya, khususnya di bidang biologi. Tujuan dari penelitian ini ialah untuk mengetahui pengaruh laboratorium virtual berbasis problem solving terhadap kemampuan berpikir kritis mahasiswa. Selain untuk meningkatkan keterampilan dan manfaat lain yang telah dijelaskan pada kalimat sebelumnya, penelitian ini juga bermanfaat memberikan masukan kepada pendidik untuk mendapatkan gambaran tentang pengaruh laboratorium virtual berbasis problem solving terhadap kemampuan berpikir kritis mahasiswa.

\section{METODE}

Penelitian ini merupakan penelitian kuantitatif. Desain penelitian ini adalah one sample pre-test-post test design yaitu suatu rancangan yang dilakukan pada satu kelompok subyek yang diberikan perlakuan (intervensi) untuk melihat efek sebelum diberi perlakuan penerapan laboratorium virtual.

\section{Prosedur}

Penelitian ini dilakukan di salah satu universitas swasta yang berada di kota Medan yaitu Universitas Imelda Medan yang berakreditasi B. Penelitian ini dilakukan pada bulan januari 2020 sampai dengan Juli 2020. Pre-test kemampuan berpikir kritis mahasiswa akan dilakukan pada bulan Februari 2020, setelah dilakukan pre-test selanjutnya akan dilakukan penerapan intervensi dengan melakukan kegitan praktium dengan mengunakan virtual laboratorium yang akan dilakukan pada bulan Maret 2020 sampai dengan bulan Juni 2020, selanjutnya akan dilakukan post-tes kemampuan berpikir kritis pada bulan Juli 2020. Pengukuran yang dilakukan terhadap kemampuan berpikir kritis menggunakan instrument soal yang menerapkan prinsip High Order Thingking (HOT) dengan penempatan kategori kognitif soal C4-C6.

\section{Analisis Data}

Untuk mengetahui apakah ada pengaruh intervensi terhadap kemampuan berpikir kritis, sebelum (pre-test) dan sesudah (pos-test) pemberian intervensi, maka uji yang digunakan dalam penelitian ini adalah uji statistik paired $t$ test, Sebelum melakukan uji, peneliti melakukan uji normalitas dengan metode analisis secara komputerisasi menggunakan Kolmorogov-Smirnovtest dengan nilai kemaknaan $(p>0,05)$. Analisis berikutnya dilakukan untuk melihat pengaruh laboratorium virtual berbasis problem solving terhadap kemampuan berpikir kritis dengan menggunakan paired t-test.

\section{HASIL DAN PEMBAHASAN}

Berdasarkan penelitian dengan menerapkan praktikum virtual pada konsep biologi sel dan molekuler. Diperoleh data nilai kemampuan berpikir kritis mahasiswa. Hasil 
penelitian tersebut diuraikan sebagai berikut. Nilai kemampuan berpikir kritis mahasiswa diperoleh dari hasil pretest dan posttest.

Tabel 1. Distribusi frekuensi Pre test kemamuan berpikir kritis $(\mathrm{N}=63)$

\begin{tabular}{lcc}
\multicolumn{1}{c}{ Kemampuan Berpikir Kritis } & F & $(\boldsymbol{\%})$ \\
\hline Sangat baik & 28 & 39,7 \\
Baik & 38 & 60,3 \\
\hline Jumlah & 63 & 100 \\
\hline
\end{tabular}

Berdasarkan Tabel 1 di atas menunjukkan bahwa hasil penelitian yang telah dilakukan diperoleh distribusi frekuensi berdasarkan tingkat kemampuan berpikir kritis sebelum dilakukan intervensi (pre test) penerapan praktikum melalui laboratorium virtual berbasis problem solving adalah mayoritas baik yaitu sebanyak 38 orang $(60,3 \%)$ dan minoritas adalah sangat baik yaitu sebanyak 28 orang $(39,7 \%)$.

Tabel 2. Distribusi frekuensi Post test kemamuan berpikir kritis $(\mathrm{N}=63)$

\begin{tabular}{lcc}
\hline \multicolumn{1}{c}{ Kemampuan Berpikir Kritis } & F & $(\mathbf{\% )}$ \\
\hline Sangat baik & 59 & 93,7 \\
\hline Baik & 4 & 6,3 \\
\hline Jumlah & 63 & 100 \\
\hline
\end{tabular}

Berdasarkan Tabel 2 di atas menunjukkan bahwa hasil penelitian yang telah dilakukan diperoleh distribusi frekuensi berdasarkan tingkat kemampuan berpikir kritis setelah dilakukan intervensi (post test) penerapan praktikum melalui laboratorium virtual berbasis problem solving adalah mayoritas sangat baik yaitu sebanyak 59 orang $(93,7 \%)$ dan minoritas adalah baik yaitu sebanyak 4 orang (6,3\%).

Setelah dilakukan pengumpulan data dan uji normalitas, bahwa data berdistribusi normal, selanjutnya dilakukan uji paired t-test untuk mengetahui pengaruh variabel independen dan variabel dependen yaitu engaruh laboratorium virtual berbasis problem solving terhadap kemampuan berpikir kritis.
Hasil uji statistik dapat dilihat pada Tabel berikut ini.

Tabel 3. Uji Statistik Kemampuan Berpikir Kritis $(\mathrm{N}=63)$

\begin{tabular}{llll}
\hline Intervensi & Rataan & t & Uji 2-arah \\
\hline Sebelum & 73.86 & & \\
Sesudah & 86.68 & -12.852 & 0,000 \\
\hline
\end{tabular}

Dari uji statistik diatas bahwa kemampuan berpikir kritis sebelum dan sesudah dilakukan penerapan praktikum laboratorium virtual berbasis problem solving ditemukan bahwa terdapat pengaruh yang signifikan terhadap kemampuan berpikir kritis dengan menggunakan uji paired t-test dengan hasil yaitu $p=0,000<0,05$. Hal ini menunjukkan bahwa penerapan praktikum dengan laboratorium virtual berbasis problem solving berpengaruh positif terhadap kemamuan berpikir kritis.

\section{Pembahasan}

Hasil penelitian menunjukkan distribusi frekuensi berdasarkan tingkat kemampuan berpikir kritis sebelum dilakukan intervensi (pre test) penerapan praktikum melalui laboratorium virtual berbasis problem solving adalah mayoritas baik yaitu sebanyak 38 orang $(60,3 \%)$ dan minoritas adalah sangat baik yaitu sebanyak 28 orang $(39,7 \%)$. Hasil penelitian yang telah dilakukan diperoleh distribusi frekuensi berdasarkan tingkat kemampuan berpikir kritis setelah dilakukan intervensi (post test) penerapan praktikum melalui laboratorium virtual berbasis problem solving adalah mayoritas sangat baik yaitu sebanyak 59 orang $(93,7 \%)$ dan minoritas adalah baik yaitu sebanyak 4 orang $(6,3 \%)$.

Temuan ini menunjukkan bahwa praktikum virtual pada mata kuliah biologi sel dan molekuler secara konsisten meningkatkan kemampuan berpikir kritis mahasiswa Program Studi Sarjana Farmasi dengan kategori sangat baik. Peningkatan ini terjadi karena praktikum virtual dapat memfasilitasi mahasiswa melatih 
kemampuan berpikir kritisnya dengan kegiatan penyelidikan konsep biologi sel dan molekuler. Konsep biologi sel dan molekuler memuat banyak materi-materi abstrak yang sulit dijangkau oleh peserta didik, sehingga penggunaan laboratorium virtual dapat menunjang kemampuan peserta didik. Hal tersebut didukung oleh penelitian sebelumnya. Menurut Fonna, et al., (2013) laboratorium virtual mampu meningkatkan kemampuan dan keterampilan peserta didik dalam memahami konsep yang abstrak. Menurut Najib, et al, (2013) laboratorium virtual menjadi alat penghubung pembelajaran dalam memberikan peningkatan pemahaman materi dan keterampilan kepada peserta didik.

Hasil penelitian ini menyatakan bahwa seluruh peserta didik mampu meningkatkan kemampuan berpikir kritis dan peserta didik dapat dinyatakan tuntas secacara keseluruhan. Hal ini sesuai dengan penelitian Prafianti \& Lutfi (2015) yang menyatakan bahwa peserta didik memperoleh ketuntasan klasikal setelah penerapan laboratorium virtual. Hal tersebut didukung oleh penelitian Bakti, et al., (2013) yang menyatakan laboratorium virtual memiliki keunggulan dalam proses pembelajaran dan kegiatan praktikum serta secara efektif dan efisien meningkatkan kemampuan berpikir kritis peserta didik.

Proses belajar mengajar pada mata kuliah Biologi sel dan molekuler dapat ditingkatkan dengan penambahan komponen laboratorium yang sesuai. Namun, untuk sebagian besar topik, kegiatan praktikum pada laboratorium terbukti terlalu mahal, memakan waktu, atau lama untuk memungkinkan siswa memperkuat konten abstrak dan konsep yang diajarkan di kelas. Pendekatan pembelajaran berbasis problem solving yang dipadukan dengan laboratorium virtual dapat membantu dalam meningkatkan pembelajaran dan pengajaran Biologi. Ini dimaksudkan untuk memberikan alternatif dari modul laboratorium tradisional.
Modul yang dikembangkan di laboratorium virtual membantu memberikan keunggulan tertentu dibandingkan teknologi pembelajaran dan pengajaran konvensional karena kendala dalam melakukan eksperimen di laboratorium konvensional. Kegiatan pembelajaran berbasis problem solving pada laboratorium virtual mampu meningkatkan standar keselamatan dan mengurangi waktu serta biaya praktikum dalam melakukan eksperimen. Hasil temuan menunjukkan bahwa tingginya baiaya yang harus dileuarkan selama kegiatan praktikum dan juga adanya pertimbangan keamanan dari penggunaan reagen atau protokol tertentu sering kali menentukan eksperimen yang dapat dilakukan peserta didik (Hiong, 2013). Penerapan kegiatan praktikum melalui laboratorium berbasis virtual menunjukkan peserta didik secara realistis dapat menggambarkan pemaparan dengan baik terhadap percoabaan yang belum pernah dilakukan sebelumnya akibat adanya kendala yang disebutkan sebelumnya. Hal tersebut menunjukkan bahwa peserta didik mampu mengasah kemampuan berpikir krtitisnya melalui permasalahan yang disajikan dalam prosedur pelaksanaan kegiatan tersebut (Tiwari \& Singh, 2011). Menurut Jaya (2015) menyatakan bahwa laboratorium virtual dapat mendukung kegiatan praktikum di laboratorium secara interaktif, dinamis, animatif, dan aplikatif sehingga tidak membosankan. Hal ini juga dikonfirmasi oleh Pradini, et al., (2015) yang menyatakan bahwa peserta didik merasa terbantu memahami konsep materi dengan menggunakan laboratorium virtual berbasis problem solving. Laboratorium virtual ini menciptakan pengalaman baru bagi peserta didik dan pengajar, karena dengan menggunakan laboratorium virtual peserta didik dapat menggunakannya secara mandiri dan menghemat waktu untuk mengajar biologi sel dan molekuler yang bersifat abstrak. Penggunaan alat dan bahan dalam laborato- 
rium juga akan lebih efisien. Ini juga diungkapkan oleh Torres, et al., (2015). Selama waktu kegiatan, peserta didik dapat berinteraksi dengan alat dan bahan laboratorium. Bahkan saat mengikuti instruksi, peserta didik mungkin mengabaikan beberapa detail, yang bisa menyebabkan kecelakaan atau kerusakan instrumen laboratorium. Penelitian tersebut meliputi analisis pembangunan laboratorium virtual dan pengalaman pengguna selama proses pembelajaran.

Berdasarkan hasil penelitian yang telah dilaksanakan, menunjukkan adanya pengaruh penggunaan laboratorium virtual berbasis problem solving terhadap kemampuan berpikir krtis mahasiswa Program Studi Sarjana Farmasi Universitas Imelda pada pembelajaran biologi sel dan molekuler pada topik pembelahan sel. Dapat disimpulkan bahwa bahan ajar siklus pembelahan sel menggunakan laboratorium virtual berbasis problem solving berdampak positif pada skor tes kemampuan berpikir kritis. Hasil penelitian ini konsisten dengan penelitian dari beberapa penelitian lain tentang efektivitas penggunaan laboratorium virtual dalam pembelajaran proses keterampilan berpikir. Menurut Jaya (2015);Liu, et al., (2015) misalnya telah menyatakan bahwa laboratorium virtual membantu peserta didik lebih baik dalam memahami proses sains dan juga meningkatkan lebih banyak keterampilan proses sains dengan baik. Sebagai tambahan laboratorium virtual berbasis problem solving juga menyediakan pengalaman belajar yang dapat mengarah pada meningkatkan kemampuan berpikir kritis. Di kasus ini seperti rumusan masalah, pengenalan alat praktikum, praktikum prosedur kerja/langkah dan pembuatannya observasi. Selain itu, laboratorium virtual dapat menyebabkan peserta didik melaksanakan suatu ilmu aktivitas, seperti menafsirkan, memprediksi, menerapkan konsep, merencanakan penelitian, mengkomunikasikan hasil dan bertanya.
Menurut Harahap, et al., (2019) lebih lanjut menambahkan bahwa ketersediaan laboratorium virtual berbasis problem solving, menunjukkan peserta didik lebih banyak aktif melakukan kegiatan ilmiah seperti interpretasi, prediksi, hipotesis formulasi, pertanyaan, konsep menerapkan, perencanaan penelitian, dan mengkomunikasikan hasil penelitian. Oleh karena itu, dengan banyaknya alat peraga dan diskusi ilmiah antara peserta didik dan dosen, mahasiswa mampu meningkatkan keterampilan proses sains dalam berpikir kritis. Menurut Flowers (2011) juga mengatakan bahwa siswa lebih suka berpartisipasi aktif saat menggunakan laboratorium virtual dibandingkan dengan laboratorium tradisional. Data juga menunjukkan bahwa peserta didik menganggap perolehan hasil belajar yang lebih tinggi merupakan sebagai hasil dari berpartisipasi aktif saat kegiatan laboratorium virtual dibandingkan dengan laboratorium praktik tradisional.

\section{KESIMPULAN}

Hasil analisis menunjukkan distribusi frekuensi berdasarkan tingkat kemampuan berpikir kritis sebelum dilakukan intervensi (pre test) penerapan praktikum melalui laboratorium virtual berbasis problem solving memiliki rataan 73.86 dan setelah dilakukan intervensi (post test) penerapan praktikum melalui laboratorium virtual berbasis problem solving memiliki rataan 86.68. Berdasarkan data tersebut dan hasil pembahasan yang didasarkan pada permasalahan dan tujuan penelitian dapat disimpulkan bahwa terdapat pengaruh yang positif dan signifikan menunjukkan bahwa $p 0.00<0.05$ terhadap penggunaan laboratorium virtual berbais problem solving terhadap kemampuan berpikir kritis mahasiswa pada mata kuliah biologi sel dan molekuler di Program Studi Sarjana Farmasi Universitas Imelda Medan. 


\section{UCAPAN TERIMA KASIH}

Ucapan terima kasih diberikan kepada Kemenristekdikti dalam rangka pemberian dana hibah Penelitian Dosen Pemula tahun anggaran 2019, responden, LPPM dan seluruh civitas akademik Universitas Imelda Medan serta semua pihak yang tidak dapat disebutkan satu per satu.

\section{DAFTAR PUSTAKA}

Bakti, E.M.S., Suparmi \& Sunarno, W. (2013). Pembelajaran Biologi Melalui Metode Eksperimen dengan Laboratorium Riil dan Laboratorium Virtuil Ditinjau dari Kemampuan Berpikir Kritis dan Gaya Belajar Siswa. Jurnal Inkuiri, 2(3), 338-346.

Bidokhta, M., Assareh. (2011). Life-Long Learners Through Problem-Based And Self Directed Learning. Procedia Computer Science, 3(1), 14461453

Faovor, M.A., \& Ayoubi, Z. (2018). The Effect of Using Virtual Laboratory on Grade 10 Students' Conceptual Understanding and their Attitudes towards Physics. Journal of Education in Science, Environment and Health (JESEH), 4(1), 54-68

Flowers, O, L. (2011). Investigating the Effectiveness of Virtual Laboratories in an Undergraduate Biology Course. The Journal of Human Resource and Adult Learning, 7(2), 1-7.

Fonna, T.M., Adlim \& Ali, M. (2013). Perbedaan Keterampilan Berpikir Kritis Siswa melalui Penerapan Media Pembelajaran Laboratorium Virtual pada Konsep Sistem Pernapasan Manusia di SMA Negeri Unggul Sigli. Jurnal Biotik, 1(2), 67-73.

Harahap, F., Nasution, N. E. A., \& Manurung, B. (2019). The Effect of Blended Learning on Student's Learning Achievement and Science Process Skills in Plant Tissue Culture Course. International Journal of Instruction, 12(1), 521-538.

Hiong, L. C.\& K. Osman. (2013). A Conceptual Framework for the Integration of 21st Century Skills in Biology Education. Research Journal of Applied Sciences, Engineering and Technology. 6(16), 2976.

Jaya, H. (2015). Pengembangan Laboratorium Virtual Untuk Kegiatan Praktikum Dan Memfasilitasi Pendidikan Karakter Di SMK. Jurnal Pendidikan Vokasi, 2(1), 81-90.

Jorda, M. (2013). Virtual Tools: Virtual Laboratories for Eksperimental Science-an
Experience with VCL Tools. Procedia - Social and Behavioral Sciences ,106(1), 3355 - 3365.

Karantzas GC, Avery MR, Macfarlane S, Mussap A, Tooley G, Hazelwood Z. (2013). Enhancing critical analysis and problem solving skills in undergraduate psychology: An evaluation of a collaborative learning and problem based learning approach. Australian Journal of Psychology. 65(1), 38-45

Liu, D., Díaz, P,V., Riofrio, G., Sun., Barba, R. (2015). Integration of Virtual Labs into Science E-learning. Procedia Computer Science, 75(1), 95 102

Muhamad, M., Zaman, H. B., \& Ahmad, A. (2011). A Scenario-based Learning Approach Virtual Laboratory Biology (VLab-Bio). Lecture Notes in Computer Science (LNCS), 7067(2), 371-381.

Najib, A., Sulhadi, \& Sopyan, A. (2013). Pengembangan Perangkat Pembelajaran Berbasis Virtual Laboratory untuk Meningkatkan Keterampilan Berpikir Kritis Siswa. Innovative Journal of Curriculum and Educational Technology, 2(1), 172-176.

Nasution, N \& Ashar Hasairin. (2016). Analisis Sarana Dan Pemanfaatan Laboratorium IPA (Biologi) Dalam Pembelajaran Biologi Kelas XI Di SMA Swasta Nusantara Lubuk Pakam. Jurnal Pelita Pendidikan. 4(4). 31-37.

Peat, M., \& Fernandez, A. (2000). The Role Of Information Technology In Biology Education: An Australian perspective. Journal of Biological Education, 34(2), 69-73.

Pradini, N.N., Fitrihidajati. H., Isnawati. (2015). Penerapan Media Animasi Interaktif Daur Biogeokimia Terhadap Hasil Belajar Siswa, UNESA Jurnal Bioedu, 4(3), 1008- 1012.

Prafianti, R.A., \& Lutfi, A. (2015). Using of Virtual Laboratory for Learning Activity in Acid, Base, and Salt Topic in SMA Negeri 1 Manyar Gresik. UNESA Journal of Chemical Education, 4(1), 107113.

Rene R. Belecina \& Jose M. Ocampo, Jr. (2018). Effecting Change on Students' Critical Thinking in Problem Solving. EDUCARE: International Journal for Educational Studies. 10(2),109-118.

Sommer, B. A., \& Sommer, R. (2003). A Virtual Lab in Reserach Methods. Journal Of Teaching Psychology. 30 (1), 171-173.

Stuckey-Mickell, T. A., \& Stuckey-Danner, B. D. (2017). Virtual labs in the online biology course: Student perceptions of effectiveness and usability. Journal of Online Learning and Teaching. 3(2), 105-111.

Tiwari, R., \& Singh, K. (2011). Virtualisation of engineering discipline experiments for an 
Barus \& Panggabean / Jurnal Pendidikan Biologi 9 (3) (2020) 11 - 18

Internet-based remote laboratory. Australasian Journal of Educational Technology 27(4), 671-692.

Torres, F.,Tovar, N.,Egremy, C. (2015). Virtual Interactive Laboratory Applied to High Schools
Programs, Procedia Computer Science ,75(1), 233 238 . 